\title{
Clay dispersion and loss in Oxisol treated with different concentrations of limestone
}

\section{Dispersão e perda de argila em solo muito argiloso incubado com diferentes doses de calcário}

\author{
Wesley Machado ${ }^{*}$; Thadeu Rodrigues de Melo ${ }^{1}$; João Tavares Filho
}

\begin{abstract}
The addition of limestone to the soil may cause clay dispersion and loss. In this study, we aimed to estimate clay dispersion and loss in Oxisol incubated with different concentrations of limestone. To this end, soil samples were collected from a depth of 0.0-0.20 m, treated with limestone at a concentration of $1.46 \mathrm{Mg} \mathrm{ha}^{-1}$ or $2.73 \mathrm{Mg} \mathrm{ha}^{-1}$ to raise base saturation to $60 \%$ and $70 \%$, respectively, and incubated for 12 months under greenhouse conditions. Clay dispersion analysis was conducted monthly using the test tube method. The results showed that clay dispersion increased with soil $\mathrm{pH}$ and time after limestone application. However, no significant change in clay concentration was identified in the control (no limestone application). At $60 \%$ base saturation, clay loss was first observed to be significantly higher than that of the control at 4 months after application and reached a maximum at 9 months after application. At $70 \%$ base saturation, clay loss was also first observed to be significantly higher than that of the control at 4 months after application and reached a maximum at 6 months after application. Overall, our data revealed that clay dispersion due to limestone application was approximately $16 \mathrm{~g} \mathrm{~kg}^{-1}$ over a period of 12 months and increased with the increasing concentrations of $\mathrm{Ca}$ and $\mathrm{Mg}$.
\end{abstract}

Key words: Clay dispersion. Limestone application. Base saturation.

\section{Resumo}

A calagem afeta a dupla camada difusa através das cargas que ocasionam repulsão ou coesão das argilas e, como consequência, interfere na sua floculação/dispersão. O objetivo deste trabalho foi estimar a perda de argila em um Latossolo Vermelho incubado com e sem calcário em duas saturações por bases. Amostras de solo foram coletadas na camada de $0,00-0,20 \mathrm{~m}$ de profundidade e acondicionadas em vasos de $0,20 \mathrm{~m}$ de altura, com volume de $0,0049 \mathrm{~m}^{3}$. Foi utilizado o calcário dolomítico nas saturações por base de $60 \%$ e $70 \%\left(1,46\right.$ e $\left.2,73 \mathrm{Mg} \mathrm{ha}^{-1}\right)$ e a incubação foi durante 12 meses. A cada mês, uma alíquota era coletada e realizada análise da dispersão de argila pelo método da proveta. À medida que decorreu o tempo, houve aumento da quantidade de argila dispersa em função do aumento do pH. Para a saturação de bases a $60 \%$, as perdas de argila aconteceram a partir do quarto mês após aplicação do calcário, em torno de $6 \mathrm{~g} \mathrm{~kg}^{-1}$, e houve decréscimo do nono mês em diante. Para $70 \%$ de saturação foi observado aumento também no quinto mês, de $10 \mathrm{~g} \mathrm{~kg}^{-1}$ de argila perdida. A testemunha se manteve estável ao longo do período. À medida que ocorre o efeito da calagem no solo, as perdas de argila em relação à testemunha ficam em torno de $16 \mathrm{~g} \mathrm{~kg}^{-1}$ ao longo do período. Calcários com teores elevados de $\mathrm{Ca}$ e $\mathrm{Mg}$ tendem a ser mais dispersivos.

Palavras-chave: Argila dispersa. Calagem. Saturação de bases.

\footnotetext{
${ }^{1}$ Discentes, Curso de Doutorado, Programa de Pós-Graduação em Agronomia, Universidade Estadual de Londrina, UEL, Centro de Ciências Agrárias, CCA, Londrina, PR, Brasil. E-mail: w.machado@agronomo.eng.br; thadeurodrigues@hotmail.com

2 Prof. Dr., UEL/CCA, Departamento de Agronomia, Londrina, PR, Brasil. E-mail: tavares@uel.br

* Author for correspondence
} 
Soil acidification is a natural process caused by several factors, including the release of hydrogen ions by plants, dissociation of $\mathrm{CO}_{2}$, hydrolysis of $\mathrm{Al}$, use of nitrogen fertilizers, decomposition of organic matter (OM), and removal of exchangeable bases. Temperature and rainfall positively affect leaching, which intensifies soil acidification. Limestone is applied to correct soil $\mathrm{pH}$, but it also provides $\mathrm{Ca}$ and $\mathrm{Mg}$ to the plants. However, this practice can modify soil properties such as microbial populations and particle dispersion (COSTA et al., 2004).

Soil stability is often related to agricultural management, including limestone application. Clay dispersion is related to the cation exchange capacity (CEC) as well as the charge of predominant binding sites (BORTOLUZZI et al., 2008). It also involves the increase in $\mathrm{pH}$ from the point of zero charge, producing repulsive forces between the particles when negative charge is in excess. Similarly, an increase in the electric potential of the Stern layer occurs in soils with a high concentration of monovalent and divalent cations $\left(\mathrm{K}^{+}, \mathrm{Na}^{+}, \mathrm{Ca}^{2+}\right.$, and $\mathrm{Mg}^{2+}$ ), where $\mathrm{Al}^{3+}$ is replaced mainly by divalent cations in the exchange complexes of low CEC clay, facilitating dispersion (ALLEONI et al., 2009).

The interaction of electric charges on the surface of clay is the result of isomorphic substitution or radical dissociation. These interactions are directly related to the dispersion of soil particles (SPERA et al., 2008), which are affected by chemical properties such as $\mathrm{pH}$ and the electrolyte concentration of the soil solution (AZEVEDO; BONUMÁ, 2004). Consequently, limestone application influences the forces among the particles, increasing or decreasing clay loss based on the soil electrochemical alteration.

Spera et al. (2008) reported that clay dispersion increases at limestone quantities higher than 50\% of the recommended. Soprano (2002) demonstrated similar effects as well as that clay dispersion increases with the decreasing OM content. Bortoluzzi et al. (2008) showed that limestone directly influences soil particles and binding sites, leading to changes in charge and increased dispersion. Therefore, limestone application affects the physical and chemical properties of the soil and thus, it is necessary to estimate the subsequent clay losses. In this study, we aimed to estimate clay dispersion and loss in Oxisol incubated with different concentrations of limestone over a period of 12 months.

Soil was collected from the 0.00-0.20 m soil layer and passed through a $4 \mathrm{~mm}$ sieve. A composite soil sample was used for chemical and physical analyses. The particle-size distribution was determined using the pipette method as described by Claessen (1997). In brief, 1 M sodium hydroxide was added as a dispersant based on soil weight and mixed with slow stirring. Soil characterization through chemical analysis was conducted as described by Pavan et al. (1992). This characterization included the determination of: $\mathrm{pH} ; \mathrm{CaCl}_{2} 0.01 \mathrm{~mol} \mathrm{l}^{-1}$; potential acidity by the SMP buffer method; $\mathrm{Ca}$ and $\mathrm{Mg}$ extracted by $1 \mathrm{~mol}$ $1^{-1} \mathrm{KCl}$ and titrated by ethylenediaminetetraacetic acid (EDTA); $\mathrm{P}$ and $\mathrm{K}$ extracted by Mehlich-1 and analyzed by spectrophotometry at $630 \mathrm{~nm}$ and with a flame photometer, respectively; and $\mathrm{OM}$ by oxidation with $\mathrm{Cr}_{2} \mathrm{O}_{7}{ }^{2-}$ and titrated with $\mathrm{FeSO}_{4}$ by the Walkley \& Black method. The soil was analyzed prior to the experiment and the following results were obtained: $\mathrm{pH}$ (in water): $4.7 ; \mathrm{H}^{+}+\mathrm{Al}^{3+}$ : $5.2 \mathrm{cmol}_{\mathrm{c}} \mathrm{dm}^{-3} ; \mathrm{Ca}^{2+}+\mathrm{Mg}^{2+}: 3.93 \mathrm{cmol}_{\mathrm{c}} \mathrm{dm}^{-3} ; \mathrm{K}^{+}$: $0.96 \mathrm{cmol}_{\mathrm{c}} \mathrm{dm}^{-3}$; P mehlich-1: $1.82 \mathrm{mg} \mathrm{dm}^{-3}$; CEC pH 7.0: $10.1 \mathrm{cmol}_{\mathrm{c}} \mathrm{dm}^{-3}$; OM: $20.2 \mathrm{~g} \mathrm{~kg}^{-1}$; and clay: $702 \mathrm{~g} \mathrm{~kg}^{-1}$. The soil was classified as dystrophic red latosol, also known as Oxisol (EMBRAPA, 2013).

The concentration of limestone required to raise the base saturation of the soil to $60 \%$ and $70 \%$ was $1.46 \mathrm{Mg} \mathrm{ha}^{-1}$ (low-level limestone application) and 2.73 $\mathrm{Mg} \mathrm{ha}^{-1}$ (high-level limestone application), respectively, which was calculated using the equation:

$$
\mathrm{NC}=(\mathrm{V} 2-\mathrm{V} 1) \mathrm{T} / \mathrm{TRNP},
$$

where V2 is the desired base saturation, V1 is the 
current base saturation, $\mathrm{T}$ is the total $\mathrm{CEC}$, and TRNP is the total relative neutralizing power of limestone.

The concentration of $\mathrm{CaO}$ and $\mathrm{MgO}$ in the limestone was measured using atomic absorption spectrophotometry as described by Silva (2009). In brief, $1 \mathrm{~g}$ of limestone was mixed with $50 \mathrm{ml}$ of 0.5 $\mathrm{M} \mathrm{HCl}$. After boiling and cooling, the volume was adjusted to $100 \mathrm{ml}$. Next, an aliquot, containing a maximum of $100 \mu \mathrm{g} \mathrm{Ca}$ and $60 \mu \mathrm{g} \mathrm{Mg}$, was used for spectrophotometric analysis. The obtained values were used in the following equations: $\mathrm{CaO} \%=$ $0.35 \mathrm{CD} / \mathrm{AG}$ and $\mathrm{MgO} \%=2.0731 \mathrm{CD} / \mathrm{AG}$, where $\mathrm{C}$ is $\mathrm{Ca}$ or $\mathrm{Mg}$ concentration (ppm); $\mathrm{D}$ is the dilution factor ( $\mathrm{D}=1$, if not diluted); $\mathrm{A}$ is the aliquot at the final dilution ( $\mathrm{ml}$ ); and $\mathrm{G}$ is the initial sample weight (g). The content of $\mathrm{CaO} \cdot \mathrm{MgO}$ was estimated to be $39.6 \%$.

The experiment was conducted in a greenhouse at Universidade Estadual de Londrina, Londrina,

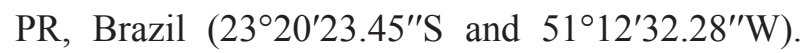
Sieved soil was added in pots $\left(0.0049 \mathrm{~m}^{3}\right.$, volume), enriched with limestone at two different concentrations, and irrigated with distilled water up to $100 \%$ field capacity over a period of 12 months. The experiment was arranged as a completely randomized design with three replications per treatment. The treatments were as follows: no limestone application (control); low-level limestone application (60\% base saturation); and high-level limestone application (70\% base saturation). On a monthly basis, a tube-type sampler was used to collect approximately $50 \mathrm{~g}$ of soil, and the middle third of the samples was used to calculate clay dispersion as described by Claessen (1997).

Data were tested for normality by the ShapiroWilk test and for homogeneity by Bartlett's test. Analysis of variance in conjunction with Tukey's test was carried out to identify significant differences between treatments. Pearson's correlation was used to identify significant associations between $\mathrm{pH}$ and clay dispersion. The level of statistical significance was set at $5 \%$.

Over a period of 12 months, clay loss was significantly lower in the control than in the limestone application treatments (Table 1). Additionally, clay loss was higher in the highlevel limestone application than in the low-level limestone application. It is known that limestone is applied to neutralize the acidity of the soil and cover the nutritional needs of plants with respect to $\mathrm{Ca}$ and $\mathrm{Mg}$. However, an unsuitable application can cause variations in soil structure and, consequently, lead to clay dispersion (ALBUQUERQUE et al., 2003).

Table 1. Differences in clay dispersion $\left(\mathrm{g} \mathrm{kg}^{-1}\right)$ over a period of 12 months between the control and limestone application treatment and between low-level and high-level limestone application treatments.

\begin{tabular}{lc}
\hline Treatment & Accumulated clay dispersion $\mathbf{( g ~ \mathbf { ~ k g } ^ { - 1 } )}$ \\
\hline Control & $1,519.3 \mathrm{~b}$ \\
Limestone application & $1,602.5 \mathrm{a}$ \\
& \\
Low-level limestone application $\left(1.46 \mathrm{Mg} \mathrm{ha}^{-1}\right)$ & $1,574.3 \mathrm{~b}$ \\
High-level limestone application $\left(2.73 \mathrm{Mg} \mathrm{ha}^{-1}\right)$ & $1,630.7 \mathrm{a}$ \\
\hline
\end{tabular}

Different letters indicate significant differences at $5 \%$ level. 
In the present study, clay dispersion in the control was relatively high, but still markedly lower than that in the limestone application treatments (Table 1). Alcarde (2005) reported that clay loss increases with the increasing content of $\mathrm{CaO} \cdot \mathrm{MgO}$ in the applied limestone. In the present study, the application of limestone with a $\mathrm{CaO} \cdot \mathrm{MgO}$ content of $39.6 \%$ caused clay dispersion of $1,602.5 \mathrm{~g} \mathrm{~kg}^{-1}$. Additionally, the degree of clay dispersion increased with the increasing amount of applied limestone; clay dispersion was $3.45 \%$ higher in the high-level limestone application compared with that in the low-level limestone application $\left(1,630.7 \mathrm{~g} \mathrm{~kg}^{-1} \mathrm{vs}\right.$. $1,574.3 \mathrm{~g} \mathrm{~kg}^{-1}$, respectively). Clay dispersion might be also negatively related to the $\mathrm{OM}$ content, which is decreased by the increasing $\mathrm{CaO} \cdot \mathrm{MgO}$ content in the applied limestone; the OM content was $8 \%$ lower in the high-level limestone application compared with that in the low-level limestone application (18.1 $\mathrm{g} \mathrm{kg}^{-1}$ vs. $\left.19.6 \mathrm{~g} \mathrm{~kg}^{-1}\right)$. OM can complex polyvalent cations and increase the negative charge on colloid surfaces. Ernani et al. (2002) reported that the activity of microorganisms increases in a conducive chemical environment, leading to increased OM degradation. The dispersive effect of $\mathrm{OM}$ is due to the presence of organic anions that decrease the ionic strength of the soil solution and is related to a complex, which is formed between divalent and trivalent cations and expands the diffuse double layer (CHENU et al., 2001).

It is known that the dispersive effect of limestone occurs at the initial stages after the application (SOPRANO, 2002). In the present study, we observed that dispersion occurred at 4 months after the application and aimed to estimate the extent of clay losses based on simple calculations. Considering that 1 ha included 2 million $\mathrm{kg}$ of soil with a density of $1 \mathrm{~kg} \mathrm{~m}^{-3}$ and that the current amount of clay was $702 \mathrm{~g} \mathrm{~kg}^{-1}$, we estimated that the accumulated clay loss was approximately 139,698 $\mathrm{kg} \mathrm{y}^{-1}$ under greenhouse conditions. However, under field conditions, factors such as climate, topography, root environment, crop type, limestone type, soil texture, particle-size distribution, density, structure, and chemical properties might increase the accumulated clay loss (SPERA et al., 2008).

Limestone application seemed to increase the soil $\mathrm{pH}$, generating greater clay losses (Figure 1). Roth and Pavan (1991) reported that $\mathrm{pH} 7.0$ has a dispersive effect on unitary particles. Spera et al. (2008) demonstrated the same results when treated soil with relatively high amounts of limestone. At $60 \%$ base saturation, the highest clay dispersion value of $135 \mathrm{~g} \mathrm{~kg}^{-1}$ was observed at $\mathrm{pH} 5.7$, whereas at $70 \%$ base saturation, the highest clay dispersion value of $140 \mathrm{~g} \mathrm{~kg}^{-1}$ was observed at $\mathrm{pH} 6.0$ (Figure 1). The deprotonation of functional groups on the surface of oxides, clay edges, and OM occurs when $\mathrm{pH}$ increases, leading to the elevation of negative charges in the particles. Thus, the specific adsorption of anions thickens the diffuse double layer and facilitates dispersion (MAHANTA et al., 2014). Melo et al. (2015) demonstrated that clay dispersion depends on the balance between the net charge of ions and organic polymers in the medium.

Our data showed that clay dispersion increased with the increasing soil $\mathrm{pH}$ (Figure 1). A previous study showed that limestone application corrects the soil $\mathrm{pH}$ by increasing the insolubility of $\mathrm{Al}^{3+}$, which is substituted by $\mathrm{Ca}^{2+}$ and $\mathrm{Mg}^{2+}$, but also boosts dispersion (MELO et al., 2016). Spera et al. (2008) confirmed that clay dispersion increases with the increasing content of $\mathrm{Ca}$ and $\mathrm{Mg}$ and the decreasing content of Al.

Limestone application can have both positive and negative effects depending on various factors, including the application method, limestone type, and $\mathrm{OM}$ content. Therefore, further studies are needed to increase the efficiency of limestone application, reducing clay dispersion and improving the quality of the agricultural system. 
Figure 1. Clay dispersion $\left(\mathrm{g} \mathrm{kg}^{-1}\right)$ over a period of 12 months in relation to soil $\mathrm{pH}$ at $60 \%$ (A) and $70 \%$ base saturation (B).

Figure 1A

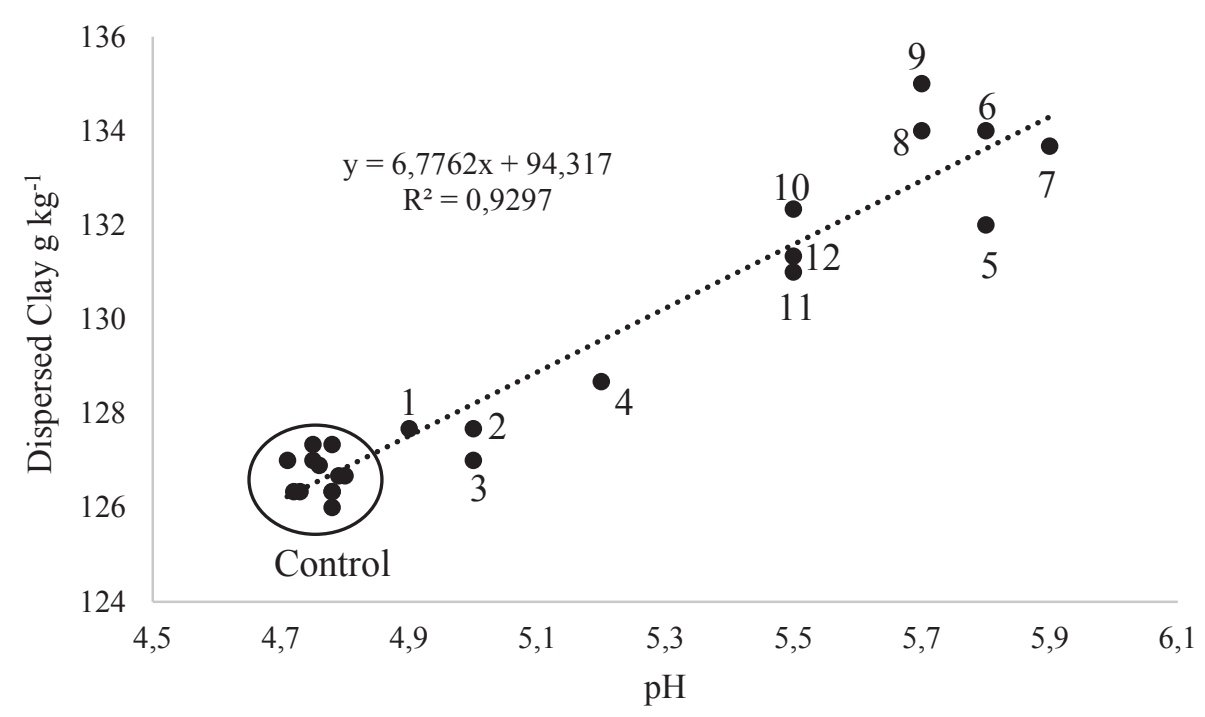

Figure 1B

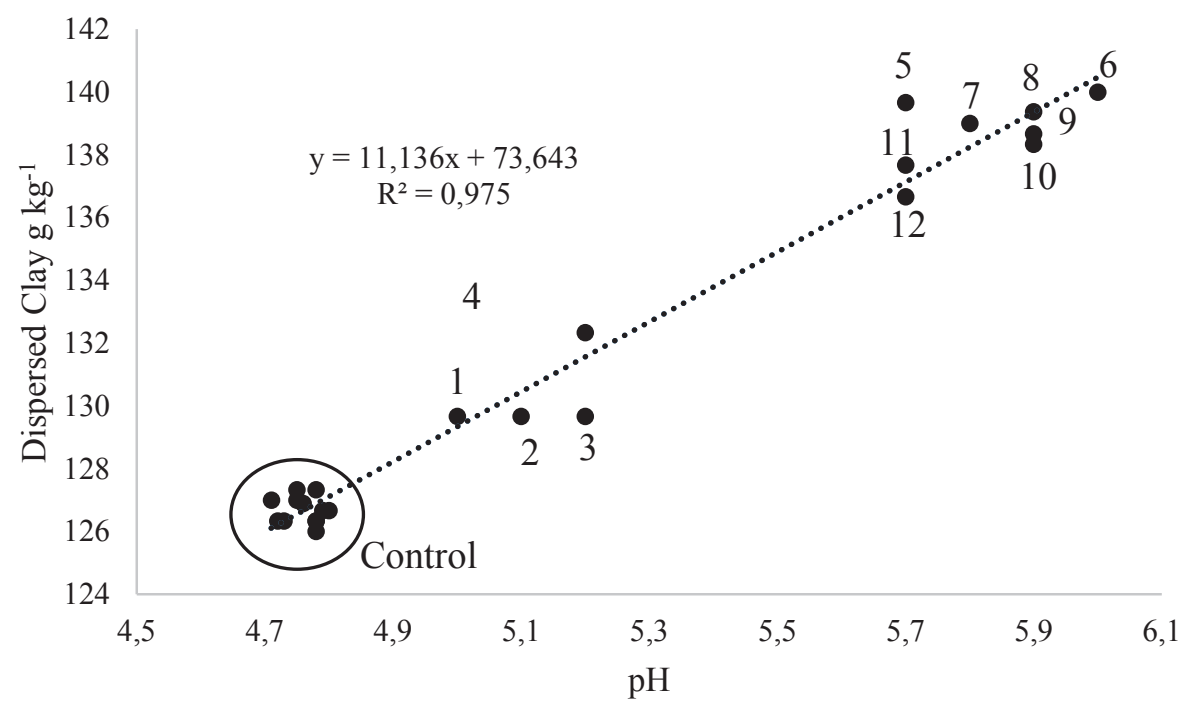

No significant change in clay concentration was identified in the control over the period of 12 months (Figure 2). At 60\% base saturation, clay dispersion was first observed to be significantly higher than that of the control at 4 months after application and reached the highest value $\left(9 \mathrm{~g} \mathrm{~kg}^{-}\right.$ $\left.{ }^{1}\right)$ at 9 months after application (Figure 2A). At $70 \%$ base saturation, clay dispersion was also first observed to be significantly higher than that of the control at 4 months after application and reached the highest value $\left(10 \mathrm{~g} \mathrm{~kg}^{-1}\right)$ at 6 months after application (Figure 2B). Our results showed that changes in the chemical composition of the soil, including $\mathrm{pH}$, ionic strength of soil solution, and ionic presence (ALBUQUERQUE et al., 2003), significantly affected clay dispersion (Figure 2). Alterations in the surface of colloids change the attraction forces, leading to particle dispersion. 
Figure 2. Clay dispersion $\left(\mathrm{g} \mathrm{kg}^{-1}\right)$ over a period of 12 months in the control and limestone application treatment at $60 \%$ base saturation $(\mathrm{A})$ and $70 \%$ base saturation $(\mathrm{B})$.

Figure 2A

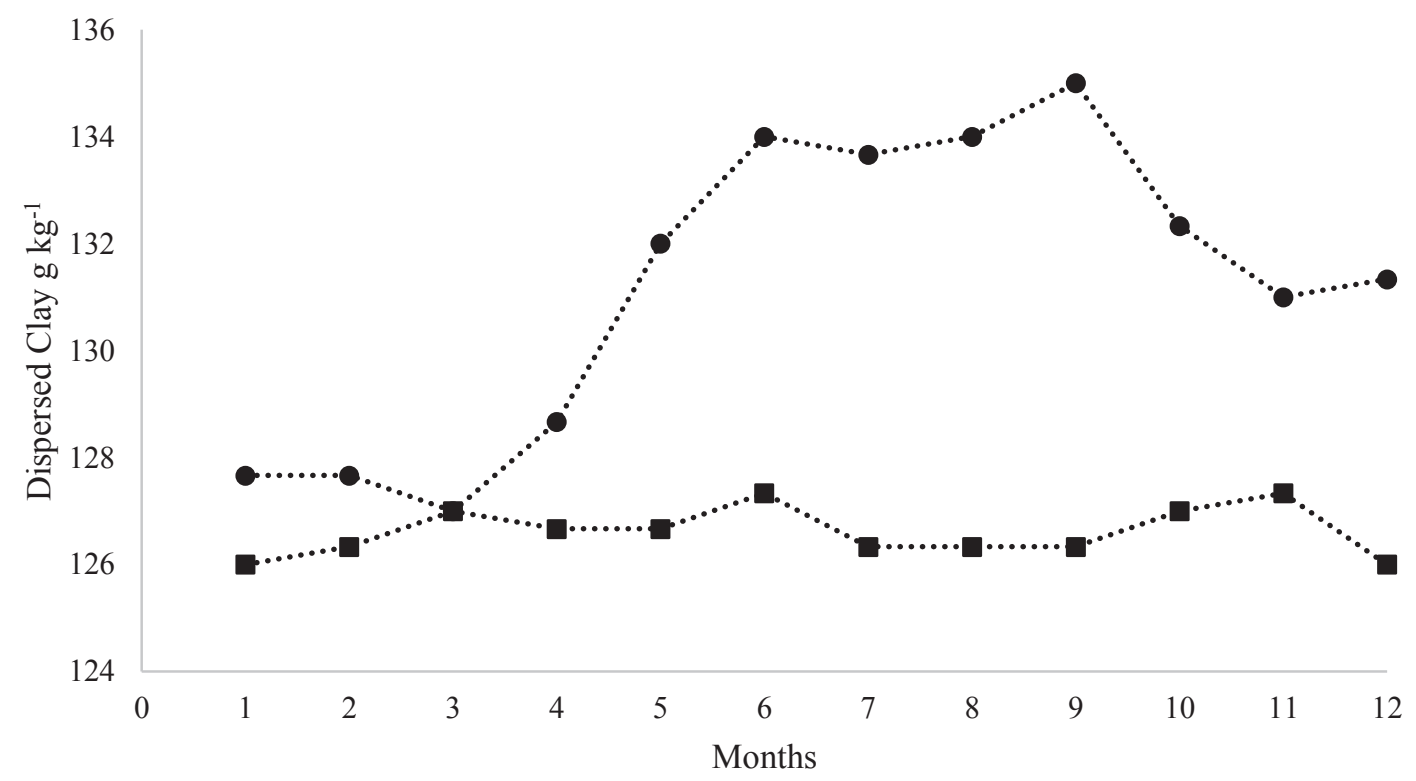

Figure 2B

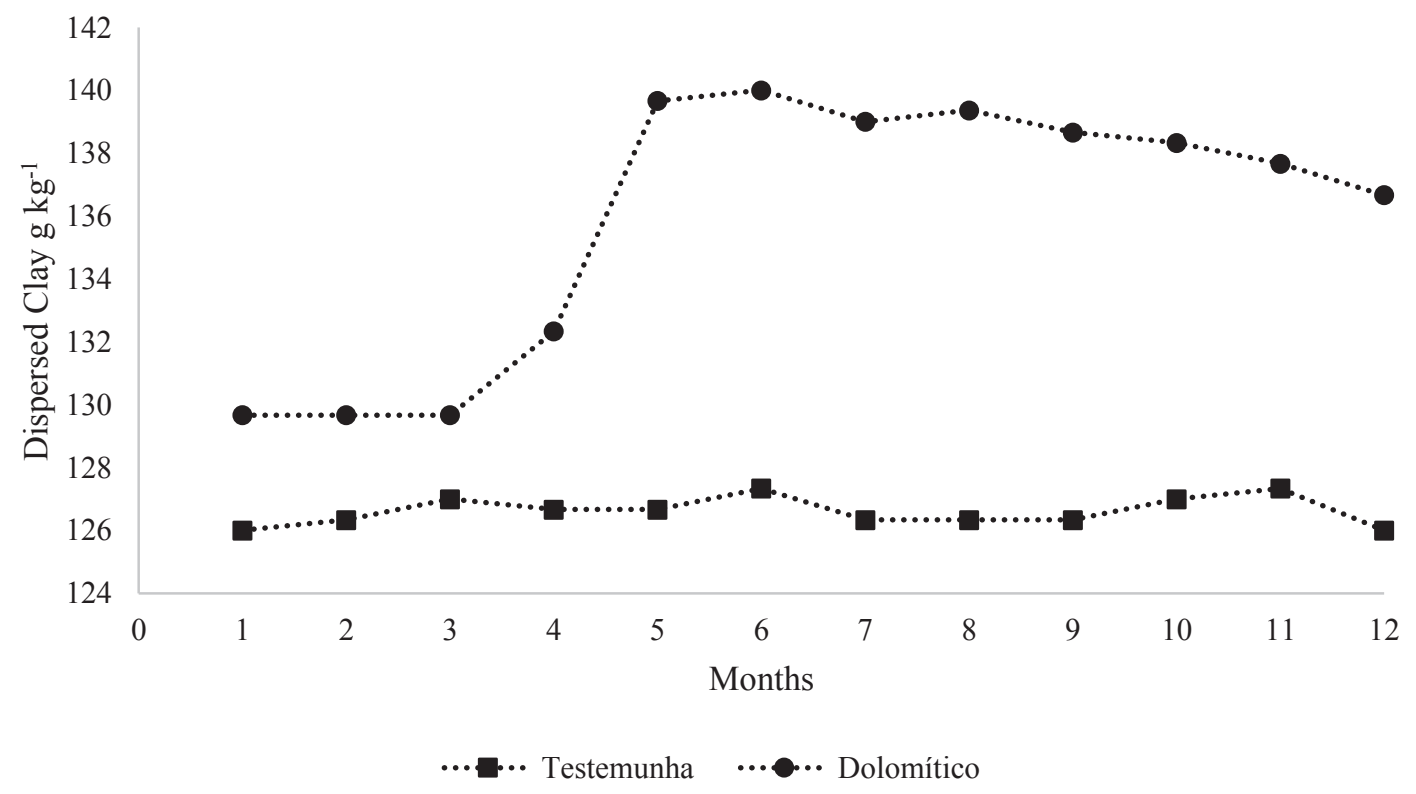

Overall, clay dispersion was higher at $70 \%$ base saturation compared with that at $60 \%$ base saturation (Figure 2), revealing that the amount of limestone significantly affects the degree of clay dispersion. At 4 months after application, the average clay loss at $70 \%$ base saturation $(118,000 \mathrm{~kg})$ was 34,000 $\mathrm{kg}$ higher than that at $60 \%$ base saturation $(84,000$ $\mathrm{kg}$ ). The $\mathrm{pH}$ increase due to limestone application increased the clay loss by $135 \mathrm{~g} \mathrm{~kg}^{-1}$ at $60 \%$ base saturation and by $140 \mathrm{~g} \mathrm{~kg}^{-1}$ at $70 \%$ base saturation over the period of 12 months of soil incubation. 


\section{References}

ALBUQUERQUE, J. A.; BAYER, C.; ERNANI, P. R.; MAFRA, A. L.; FONTANA, E. C. Aplicação de calcário e fósforo e estabilidade da estrutura de um solo ácido. Revista Brasileira de Ciência do Solo, Viçosa, MG. v. 27, n. 5, p. 799-806, 2003.

ALCARDE, J. C. Corretivos da acidez dos solos: características e interpretações técnicas por J. C. Alcarde. ANDA. São Paulo: ANDA, 2005. (ANDA, Boletim técnico, 6).

ALLEONI,L.R.F.; CAMARGO,A.O.; CASAGRANDE, J. C.; SOARES, M. R. Química dos solos altamente intemperizados. In: MELO, V. F.; ALLEONI, L. R. F. Química e mineralogia do solo. Viçosa, MG: Sociedade Brasileira de Ciência do Solo, 2009. v. 2, p. 381-447.

AZEVEDO, A. C.; BONUMÁ, A. S. Partículas coloidais, dispersão e agregação em Latossolos. Ciência Rural, Santa Maria, v. 34, n. 2, p. 609-617, 2004.

BORTOLUZZI, E. C.; GARBOZZA, L.; GUARESCHI, C.; RHEINHEIMER, D. S. Efeito da calagem na relação entre solo e água. Revista Brasileira de Ciência Solo, Viçosa, MG, v. 32, p. 2621-2628, 2008. Número Especial.

CHENU, C. L. E.; BISSONNAIS, Y.; ARROUAYS, D. Organic matter influence on clay wettability and soil aggregate stability. Soil Science Society American Journal, Madison, v. 64, n. 4, p. 1479-1486, 2001.

CLAESSEN, M. E. C. (Org.). Manual de métodos de análise de solos. 2. ed. Rio de Janeiro: Embrapa-Solos 1997. 212 p. Disponível em: <https://www.agencia. cnptia.embrapa.br/Repositorio/Manual+de+Metodos 000fzvhotqk02wx5ok0q43a0ram31wtr.pdf>. Acesso em: 06 set. 2017.

COSTA, F. S.; BAYER, C.; ALBUQUERQUE, J. A.; FONTOURA, S. M. V. Calagem e as propriedades eletroquímicas e físicas de um Latossolo em plantio direto. Ciência Rural, Santa Maria, v. 34. n. 1, p. 281284, 2004.

EMPRESA BRASILEIRA DE PESQUISA AGROPECUÁRIA - EMBRAPA. Sistema brasileiro de classificação de solos. 3. ed. Rio de Janeiro: Embrapa Solos, 2013. 353 p.
ERNANI, P. R.; BAYER, C.; MAESTRI, L. Corn yield as affected by liming and tillage system on an acid Brazilian Oxisol. Agronomy Journal, Madison, v. 94, n. 94, p. 305-309, 2002.

MAHANTA, K. K.; MISHRA, G. C.; KANSAL, M. L. Estimation of the electric double layer thickness in the presence of two types of ions in soil water. Applied Soil Science, Amsterdam, v. 87, n. 5, p. 212-218, 2014.

MELO, T. R.; MACHADO, W.; TAVARES FILHO, J. Correlation of cationic indices with clay dispersion degree of two soils from Brazil fertilized with chicken manure. International Journal of Plant \& Soil Science, Delaware, v. 4. n. 4, p. 338-351, 2015.

MELO, T. R.; TELLES, T. S.; MACHADO, W. S.; TAVARES FILHO, J. Factors affecting clay dispersion in Oxisols treated with vinasse. Semina: Ciências Agrárias, Londrina, v. 37, n. 6, p. 3997-4004, 2016.

PAVAN, M. A.; BLOCH, M. F.; ZEMPULSKI, H. C.; MIYAZAWA, M.; ZOCOLER, D. C. Manual de análise química de solo e controle de qualidade. Londrina: Instituto Agronômico do Paraná, 1992. 39 p. (Circular, 76).

ROTH, C. H.; PAVAN, M. A. Effects of lime and gypsum on clay dispersion and infiltration in samples of a Brazilian Oxisol. Geoderma, Amsterdam, v. 48, n. 3, p. 351-361, 1991.

SILVA, F. C. (Ed.). Manual de análises químicas de solos, plantas e fertilizantes. 2. ed. Brasília: Embrapa Informação Tecnológica, 2009. 627 p.

SOPRANO, E. Estabilidade de agregados e dispersão de argila em função da calagem. 2002. Tese (Doutorado em Agronomia) - Universidade Federal do Rio Grande do Sul, Porto Alegre.

SPERA, S. T.; DENARDIN, J. E.; ESCOSTEGUY, P. A. V.; SANTOS, H. P.; FIGUEROA, E. A. Dispersão de argila em microagregados de solo incubado com calcário. Revista Brasileira de Ciência do Solo, Viçosa, MG, v. 32, p. 2613-2620, 2008. Número Especial. 
